\title{
Implementasi Bimbingan Kelompok dengan Tekhnik Diskusi untuk Meningkatkan Minat Belajar Peserta
}

\author{
Hardiyansyah Masya, Arifin Efendi
}

Dosen dan Mahasiswa Fakultas Tarbiyah dan Keguruan, IAIN Raden Intan Lampung

Diterima: April 2015. Disetujui: Mei 2015. Dipublikasikan: Juni 2015

\begin{abstract}
Abstrak: Tujuan penelitian ini adalah untuk meningkatkan minat belajar Matematika peserta didik kelas XI IPS SMA Negeri 6 Bandar Lampung dengan menggunakan bimbingan kelompok dengan teknik diskusi. Metode yang digunakan pada penelitian ini adalah penelitian quasi experimental. Populasi penelitian ini adalah peserta didik kelas XI IPS SMA Negeri 6 Bandar Lampung adalah 119 maka sampel penelitian adalah $25 \%$ yaitu 30 peserta didik dengan menyesuaikan tujuan penelitian menggunakan random sampling. Adapun tekhnik pengumpulan data menggunakan quesioner, observasi, wawancara dan dokumentasi. Hasil analisis data Gambaran minat belajar pada peserta didik kelas XII IPS SMA Negeri 6 Bandar Lampung bahwa terdapat peningkatan minat belajar baik dari kelompok eksperimen maupun kelompok kontrol. Terdapat 34,77\% menjadi 73,44\% dengan demikian menjelaskan bahwa pada kelompok eksperimen mengalami peningkatan minat belajar sebanyak 38,67\% dan pada kelompok kontrol dari 48,82\% menjadi 59,85\% ini menunjukan bahwa ada peningkatan pada kelompok kontrol sebanyak $11,03 \%$.
\end{abstract}

Kata Kunci : Bimbingan Kelompok, Tekhnik Diskusi, dan Minat Belajar

\section{Pendahuluan}

Berdasarkan tujuan dari pendidikan Islam dan pendidikan nasional, maka dapat dipahami bahwa seorang peserta didik diharapkan mampu menjadi makhluk yang berguna di dunia maupun di akhirat, dimana hal tersebut dapat diwujudkan dengan meningkatkan minat belajar baik dalam akademik maupun non akademik. Dalam proses pembelajaran, hal-hal yang harus diperhatikan adalah adanya berbagai macam faktor yang dapat menghambat tujuan pembelajaran, salah satu diantaranya adalah adanya minat belajar peserta didik. Sebagaimana yang dikemukakan oleh Bimo Walgito, bahwa: "apabila anak telah mempunyai minat belajar, maka akan mendorong individu itu berbuat sesuai dengan minatnya dan minat itu memperbesar motif yang ada pada individu. Berhubungan dengan itu maka perlu dibangkitkan adanya minat dari anak-anak". (Walgito, 2005) Hurlock juga menjelaskan bahwa minat merupakan sumber motivasi yang mendorong orang untuk melakukan apa yang mereka inginkan (Muhibin Syah, 2001).

Berdasarkan pendapat tersebut, maka dapat disimpulkan bahwa dengan adanya minat belajar, maka peserta didik akan lebih mudah mempelajari suatu materi pelajaran. Akan tetapi yang menjadi permasalahannya adalah bagaimana seorang guru dapat memberikan bimbingan kepada peserta didik, sehingga peserta didik tersebut memiliki minat belajar yang tinggi terhadap mata pelajaran yang dipelajarinya. Dengan demikian menjadi tanggung jawab lembaga- lembaga pendidikan untuk menyediakan lingkungan yang dipercayai anak-anak dan remaja guna merangsang minat para pelajar terhadap banyaknya kegiatan yang bermanfaat. Minat yang telah disadari terhadap bidang pelajaran, mungkin sekali akan menjaga pikiran peserta didik sehingga bisa menguasai pelajarannya. Pada gilirannya, prestasi yang berhasil akan menambah minatnya yang akhirnya bisa berlanjut sepanjang hayatnya. Karenanya keseluruhan proses pendidikan, kegiatan belajar merupakan kegiatan yang inti atau utama. Sebagaimana telah dikemukakan sebelumnya bahwa pendidikan itu sendiri dapat diartikan sebagai bantuan perkembangan dengan melalui kegiatan belajar (Nursalim, 2015). 
Peserta didik yang memiliki minat belajar yang baik dapat dilihat dari indikator ketertarikan, perasaan suka/senang, partisipasi, dan perhatian peserta didik. (Slameto, 2010) Namun berdasarakan hasil prasurvei yang dilakukan dengan menyebar angket bahwa fenomena yang terjadi kepada peserta didik kelas XI IPS SMA Negeri 6 Bandar Lampung mempunyai minat atau keinginan belajar yang rendah khususnya pada pelajaran Matematika dapat dilihat pada tabel berikut:

Tabel 1. Minat belajar matematika peserta didik kelas XI IPS SMA Negeri 6 Bandar

\begin{tabular}{clll}
\hline No & Kriteria & $\begin{array}{c}\text { Jumlah } \\
\text { Peserta } \\
\text { didik }\end{array}$ & Presentase \\
\hline 1 & $\begin{array}{l}\text { Sangat } \\
\text { tinggi }\end{array}$ & 7 & $5,88 \%$ \\
\hline 2 & Tinggi & 15 & $12,60 \%$ \\
\hline 3 & Sedang & 32 & $26,89 \%$ \\
\hline 4 & Rendah & 39 & $32,77 \%$ \\
\hline 5 & $\begin{array}{l}\text { Sangat } \\
\text { rendah }\end{array}$ & 26 & $21,84 \%$ \\
\hline Jumlah & 119 & $100 \%$ \\
\hline
\end{tabular}

Dari tabel tersebut menjelaskan bahwa minat belajar peserta didik cenderung rendah terdapat 39 peserta didik $(32,77 \%)$ dan 26 peserta didik $(21,84 \%)$ yang sangat rendah. Hal ini juga diketahui berdasarkan wawancara yang dilakukan di SMA Negeri 6 Bandar Lampung banyak peserta didik yang memandang Matematika sebagai bidang studi yang paling sulit. Meskipun demikian, semua orang harus memperlajarinya karena merupakan sarana untuk memecahkan masalah kehidupan sehari-hari. Seperti halnya membaca, dan menulis, kesulitan belajar Matematika harus diatasi sedini mungkin. jika tidak peserta didik akan menghadapi banyak kesulitan dalam belajar karena hampir semua bidang studi memerlukan Matematika. Dengan kurangnya minat belajar Matematika maka hasil belajar Matematika pun lebih rendah dibandingkan dengan mata pelajaran Ekonomi, Sejarah, dan Geografi.

Hal ini dikuatkan kembali dari hasil wawancara dengan guru Matematika kelas XI IPS yaitu ibu Sulistawati, S.Pd yang menerangkan sebagai berikut: "menurut saya, anak-anak kelas XI IPS minat belajar Matematika sudah cukup, akan tetapi masih terdapat beberapa anak yang minat belajarnya masih rendah, hal ini dapat dilihat dari hasil belajar Matematika peserta didik kelas XI IPS Masih di bawah nilai KKM, diantara penyebabnya adalah anggapan- anggapan mereka tentang Matematika adalah pelajaran yang sangat sulit untuk dipahami dan menjenuhkan. Bahkan ketika ada latihan di kelas hanya sebagian kecil dari peserta didik tersebut yang berminat untuk mengerjakan secara mandiri latihan tersebut dan yang lainya hanya ikut serta dalam proses pembelajaran saja." (Sulistawati, 2015).

Berdasarkan hasil wawancara tersebut, sesuai dengan wawancara dengan peserta didik yang dapat disimpulkan sebagai berikut: "pelajaran Matematika menurut saya adalah pelajaran yang sangan susah dan sangat rumit, karena terlalu banyak rumus dan cara yang bias digunakan utuk menemukan hasilnya. Maka oleh sebab itu ketika saya dan teman-teman mendapat Pekerjaan Rumah (PR) dari guruMatematika saya enggan untuk mengerjakan tugas tersebut di rumah dan saya pun hanya mengerjakannya di kelas ketika pelajaran Matematika akan segera dimulai" (didik, 2015).

Jika hal ini terus berlanjut tampa diperhatikan maka akan menimbulkan masalah baru, karena minat sangat besar perannya sebagai motivating force yaitu sebagai kekuatan yang akan mendorong peserta didik untuk belajar. Peserta didik yang berminat (sikapnya senang) kepada mata pelajaran, proses pembelajaran dan guru yang mengajarkannya, akan tampak terdorong 
terus untuk tekun belajar. Berbeda dengan peerta didik yang sikapnya hanya menerima kepada pelajaran, mereka hanya tergerak untuk mau belajar tetapi sulit untuk bisa terus tekun karena tidak ada pendorongnya (Sabri, 2007).

Dengan adanya masalah tersebut maka peran bimbingan dan konseling adalah membantu peserta didik untuk lebih meningkatkan minat belajar khususnya pada mata pelajaran Matematika sehingga peserta didik dapat belajar secara maksimal. Adapun layanan bimbingan dan konseling yang sesuai untuk meningkatkan minat belajar peserta didik, salah satunya adalah kegiatan bimbingan kelompok dengan teknik diskusi kelompok karena di dalam kelompok peserta didik belajar berdiskusi dan membahas topik yang diangkat bersama-sama serta mencari jalan keluar untuk masalah tersebut. (Nursalim, 2015).

Dilihat dari hasil penelitian Lailatul Mufidah dan Mochamad Nursalim "Penggunaan Bimbingan Kelompok Dengan Teknik Diskusi Kelompok Untuk Meningkatkan Minat Belajar Siswa", bimbingan kelompok dengan teknik diskusi baik digunakan untuk mengatasi permasalahan peserta didik yang mengalami permasalahan minat belajar dan hasilnya terbukti bahwa bimbingan kelompok dengan teknik diskusi dapat meningkatkan minat belajat peserta didik. Oleh karena itu peneliti mengajukan implementasi bimbingan kelompok dengan teknik diskusi dalam meningkatkan minat belajar Matematika peserta didik kelas XI IPS SMA Negeri 6 Bandar Lampung.

\section{Metode Penelitian}

Adapun jumlah populasi peserta didik lebih dari 100 maka pada penelitian ini peneliti hanya mengambil 25\% dari populasi. Jumlah peserta didik kelas XI IPS SMA Negeri 6 Bandar Lampung adalah 119 maka sampel penelitian adalah 25\% yaitu 30 peserta didik dengan menyesuaikan tujuan penelitian. Metode yang digunakan pada penelitian ini adalah penelitian quasi experimental. Alasan peneliti menggunakan metode ini karena, dalam rancangan metode quasi experimental, terdapat kelompok kontrol dan kelompok eksperimen (Sugiyono, 2009) Desain eksperimen yang digunakan dalam penelitian ini adalah Non-equivalent Control Group Design. Pada dua kelompok tersebut, sama-sama dilakukan pre-test dan post-test. Namun hanya kelompok eksperimen yang diberikan perlakuan (treatment). (Creswell, 2013)

\section{Hasil Dan Pembahasan}

Penelitian ini dilaksanakan di SMA Negeri 6 Bandar Lampung tahun pelajaran 2015/2016 pada bulan Juli sampai dengan Agustus 2016, yang sesuai dengan jadwal yang telah disepakati dengan sasaran/subjek penelitian. Hasil penelitian diperoleh melalui penyebaran instrumen yang bertujuan untuk memperoleh data mengenai profil/gambaran minat belajar matematika peserta didik dan sekaligus sebagai dasar penyesuaian isi layanan bimbingan kelompok dengan teknik diskusi dalam meningkatkan minat belajar matematika peserta didik. Hasil penyebaran instrumen dijadikan analisis awal untuk perumusan layanan bimbingan kelompok dengan teknik diskusi dalam meningkatkan minat belajar matematika peserta didik yang kemudian diuji cobakan guna memperoleh keefektifan. Berdasarkan hasil uji $t$ independen sampel test pada kelompok eksperimen dan kelompok kontroluntuk meningkatkan minat belajar peserta didik didapat hasil sebagai berikut: 
Tabel 1. Hasil Uji t Independen Minat Belajar Matematika Peserta Didik Kelompok

\begin{tabular}{|c|c|c|c|c|c|c|c|}
\hline \multirow[b]{2}{*}{$\begin{array}{l}\text { Kelom } \\
\text { pok }\end{array}$} & \multicolumn{7}{|c|}{ Eksperimen dan Kontrol Secara Keseluruhan } \\
\hline & $\begin{array}{l}\text { Rata- } \\
\text { rata }\end{array}$ & $\mathrm{Sd}$ & $\begin{array}{l}\text { Perbedaan } \\
\text { Rerata }\end{array}$ & Statistik uji t & Sig & $\begin{array}{l}\text { Sig. } 2 \\
\text { Tailed }\end{array}$ & $\begin{array}{l}\text { Keteran } \\
\text { gan }\end{array}$ \\
\hline $\begin{array}{l}\text { Eksperi } \\
\text { men }\end{array}$ & 95,4667 & 13,71582 & 17,6667 & 4,567 & 0,020 & 0,000 & $\begin{array}{l}\text { Signifik } \\
\text { an }\end{array}$ \\
\hline
\end{tabular}

Berdasarkan tersebut diperoleh nilai Sig $(0,020) \geq \alpha(0,05)$, maka varians kedua kelompok tidak homogen, dan berdasarkan hasil perhitungan pengujian diperoleh thitung 4,567 pada derajat kebebasan (df) 28 kemudian dibandingkan dengan $t_{\text {tabel }} 0,05=2,048$, maka $t_{\text {hitung }}$ $\geq t_{\text {tabel }}(4,567 \geq 2,048)$, nilai sign.(2-tailed) lebih kecil dari nilai kritik $0,005(0.000 \leq 0,005)$, ini menunjukkan bahwa Ho ditolak dah Ha diterima, selain itu didapat nilai rata-rata kelompok eksperimen lebih besar dari pada kelompok kontrol $(95,4667 \geq 77,8000)$. Jika dilihat dari nilai rata-rata, maka peningkatan minat belajar pada kelompok eksperimen lebih tinggi dibanding dengan kelompok kontrol. Tabel 1 menunjukkan rata-rata peningkatan minat belajar kelompok eksperimen dan kelompok kontrol. Setelah dilakukan layanan bimbingan kelompok dengan teknik diskusi didapat hasil pretest, posttest, dan gain score sebagai berikut:

Tabel 2. Deskripsi Data Pretest, Posttest, Gain Score

\begin{tabular}{|c|c|c|c|c|c|c|c|}
\hline \multicolumn{4}{|c|}{ Kelompok Eksperimen } & \multicolumn{4}{|c|}{ Kelompok Kontrol } \\
\hline No & $\begin{array}{c}\text { Pret } \\
\text { est }\end{array}$ & $\begin{array}{c}\text { Postt } \\
\text { est }\end{array}$ & $\begin{array}{l}\text { Gain } \\
\text { Score }\end{array}$ & No & $\begin{array}{c}\text { Prete } \\
\text { st }\end{array}$ & $\begin{array}{c}\text { Post } \\
\text { test }\end{array}$ & $\begin{array}{c}\text { Gain } \\
\text { Scor } \\
e\end{array}$ \\
\hline 1 & 45 & 100 & 55 & 1 & 62 & 84 & 22 \\
\hline 2 & 45 & 96 & 51 & 2 & 59 & 73 & 14 \\
\hline 3 & 44 & 102 & 58 & 3 & 65 & 79 & 14 \\
\hline 4 & 44 & 91 & 47 & 4 & 65 & 78 & 13 \\
\hline 5 & 45 & 95 & 50 & 5 & 65 & 79 & 14 \\
\hline 6 & 45 & 83 & 38 & 6 & 65 & 76 & 11 \\
\hline 7 & 46 & 67 & 21 & 7 & 63 & 65 & 2 \\
\hline 8 & 46 & 110 & 64 & 8 & 66 & 80 & 14 \\
\hline 9 & 46 & 109 & 63 & 9 & 66 & 81 & 15 \\
\hline 10 & 46 & 106 & 60 & 10 & 66 & 80 & 14 \\
\hline 11 & 45 & 104 & 59 & 11 & 65 & 83 & 18 \\
\hline 12 & 46 & 92 & 46 & 12 & 63 & 77 & 14 \\
\hline 13 & 45 & 67 & 22 & 13 & 60 & 65 & 5 \\
\hline 14 & 46 & 104 & 58 & 14 & 60 & 83 & 23 \\
\hline 15 & 44 & 106 & 62 & 15 & 62 & 84 & 22 \\
\hline$\sum$ & 678 & 1432 & 754 & $\sum$ & 952 & $\begin{array}{c}116 \\
7\end{array}$ & 215 \\
\hline
\end{tabular}

Berdasarkan hasil perhitungan rata- rata pretest dan posttest pada kelompok eksperimen dan kelompok kontrol sama- sama mengalami kenaikan, pada kelompok eksperimen $(45,2 \leq 95,45)$ dan pada kelompok kontrol $(63,46 \leq 77,8)$. Namun, meskipun kedua kelompok sama-sama mengalami peningkatan, tetapi nilai rata-rata kelompok eksperimen lebih tinggi dan kelompok eksperimen mengalami peningkatan lebih tinggi dibandingkan dengan kelompok kontrol, hal ini dapat dilihat dari hasil posttest kelompok ekperimen lebih besar dari pada kelompok kontrol $(95,45 \geq 77,8)$. Maka, dapat disimpulkan bahwa setelah pemberian layanan bimbingan kelompok dengan teknik diskusi peserta didik mengalami peningkatan 
minat belajar. Untuk lebih jelasnya, peningkatan minat belajar dapat dilihat pada gambar berikut:

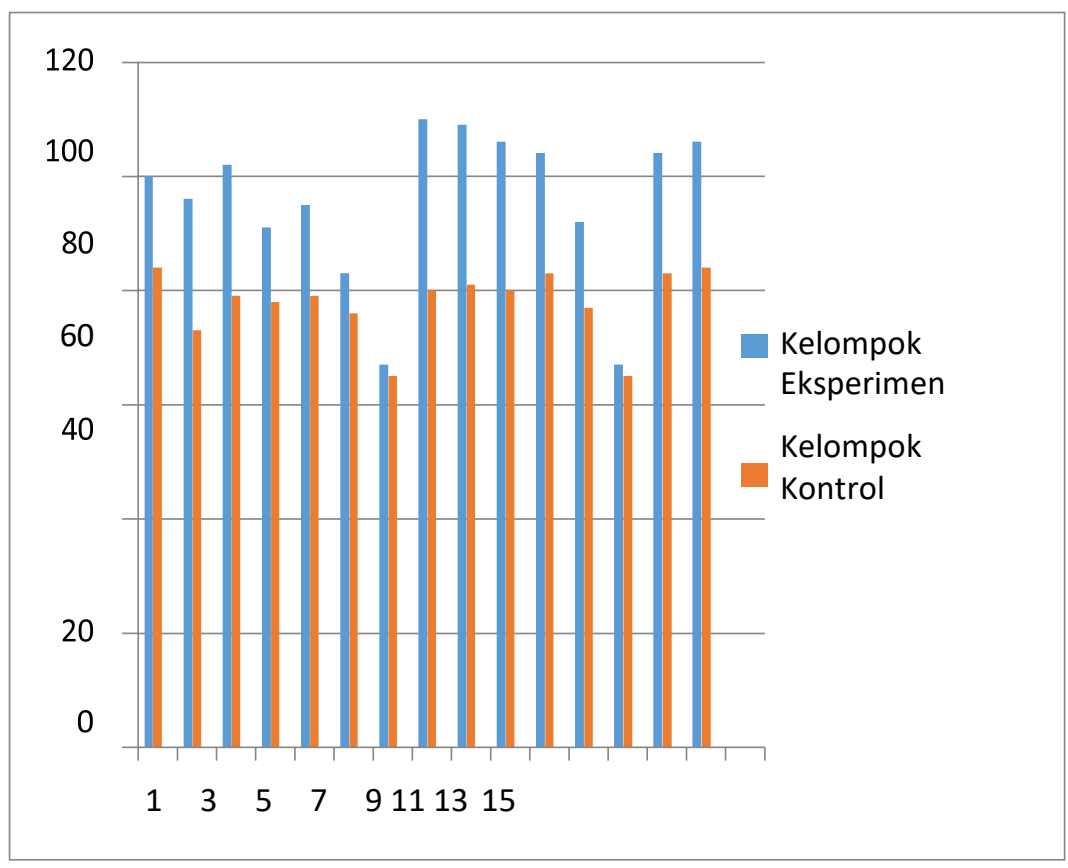

\section{Gambar 1. Grafik Peningkatan Minat Belajar Kelompok Eksperimen dan Kelompok Kontrol}

Berdasarkan hasil kegiatan layanan bimbingan kelompok dengan teknik diskusi yang dilakukan sebanyak 6 kali pada kelompok eksperimen dan 2 kali pada kelompok kontrol terdapat beberapa kesan dan komitmen anggota kelompok yang diungkapkan, yaitu dalam kegiatan layanan bimbingan kelompok banyak terdapat manfaat, dapat menambah wawasan, pengetahuan baru, mengakrabkan satu dan yang lainnya, dan peserta didik akan lebih dapat besemangat dalam belajar, tetap belajar walaupun tidak ada yang mengawasi, fokus terhadap materi yang disampaikan kepada guru, mengerjakan soal-soal yang diberikan oleh guru, dan tidak ada lagi yang sengaja datang terlambat pada saat pelajaran matematika, dan percaya diri dalam belajar.

Tujuan dalam penelitian ini adalah membantu peserta didik meningkatkan minat belajar matematika. Layanan bimbingan yang dilakukan dalam suasana kelompok dapat dijadikan media penyampaian informasi, berbagi pengalaman dan bertukar ide/pemikiran serta membantu peserta didik melakukan perilaku yang dapat meningkatkan minat belajar, serta dapat membantu peserta didik membuat keputusan yang tepat sehingga diharapkan akan berdampak positif bagi peserta didik dalam meningkatkan minat belajar.

Hal tersebut senada dengan pendapat Romlah bahwa bimbingan kelompok adalah salah satu teknik bimbingan yang berusaha membantu individu agar dapat mencapai perkembangannya secara otimal sesuai dengan kemampuan, bakat, minat, serta nilai- nilai yang dianutnya dan dilaksanakan dalam situasi kelompok. Bimbingan kelompok ditujukan untuk mencegah timbulnya masalah pada peserta didik dan mengembangkan potensi peserta didik (Budiarto, 2015) 
Tercapainya tujuan penelitian mulai terlihat dimana dinamika dalam kelompok tercipta dengan baik, sehingga anggota kelompok antusias mengungkapkan pendapatnya, pengalamannya, dan ide-ide yang berkaitan dengan materi yang dibahas karena topik yang dibahas berhubungan dengan diri mereka, adanya interaksi yang baik antara anggota dengan anggota yang lain serta para anggota dengan pimpinan kelompok. Para peserta didik merasa memiliki kedekatan antar anggota kelompok dalam hal ini terlihat peserta didik selalu hadir pada saat pelaksanaan layanan bimbingan kelompok, para anggota saling memberikan pendapat dan saran ketika kegiatan berlangsung, para anggota kelompok saling bergantian mengutarakan pendapatnya terkait materi yang dibahasa.

\section{Simpulan dan Saran}

Gambaran minat belajar pada peserta didik kelas XII IPS SMA Negeri 6 Bandar Lampung bahwa terdapat peningkatan minat belajar baik dari kelompok eksperimen maupun kelompok kontrol. Terdapat 34,77\% menjadi 73,44\% dengan demikian menjelaskan bahwa pada kelompok eksperimen mengalami peningkatan minat belajar sebanyak 38,67\% dan pada kelompok kontrol dari 48,82\% menjadi 59,85\% ini menunjukan bahwa ada peningkatan pada kelompok kontrol sebanyak 11,03\%. Hal ini menjelaskan bahwa peserta didik telah memiliki minat belajar matematika cukup baik dengan ditandai perilaku: (a) mempunyai perasaan suka dan senang dalam belajar sehingga dapat belajar secara maksimal tanpa harus ada yang memaksa atau mengawasi; (b) peserta didik dapat menfokuskan perhatiannya pada saat guru menjelaskan materi sehingga mereka dapat memahami yang disampaikan oleh guru; (c) peserta didik mulai ada ketertarikan dalam belajar sehingga mereka selalu ingin terus belajar, suka mengerjakan soal-soal latihan, dan tidak ada lagi yang tidak mengerjakan PR; dan (d) antusian peserta didik dalam belajar cukup dengan menanyakan hal-hal yang belum mereka pahami dan tidak takut salah untuk menjawab soal-soal yang diberikan.

Secara keseluruhan penelitian ini menghasilkan kesimpulan bahwa bimbingan kelompok dengan teknik diskusi efektif dalam meningkatkan minat belajar matematika peserta didik. Efektivitas bimbingan kelompok dengan teknik diskus ditandai dengan adanya peningkatan minat belajar peserta didik. Hal ini dapat dilihat dari perbedaan dan perbandingan antara hasil pretest dan posttest

\section{Daftar Pustaka}

Budiarto, A. (2015, Februari 19). Retrieved from http://azizbudiarto.blogspot.com/201 4/03/pengaruh-layanan-bimbingan- kelompok.html

Creswell, J. (2013). Research Design Pendekatan Kualitatif, Kuantitatif, dan Mixed. Yogyakarta: Pustaka Pelajar.

didik, P. (2015, januari 13). wawancara peserta didik kelas XI IPS SMA Negeri 6 Bandar Lampung,

Muhibin Syah. (2001). Psikologi Pendidikan Dengan Pendekatan Baru. Bandung: PT. Remaja Rosdakarya.

Nursalim, L. M. (2015, Februari 19). Retrieved from www.academia.edu/.../PENGGUNA AN

Sabri, A. (2007). Psikologi Pendidikan. Jakarta: Pedoman Ilmu Jaya.

Slameto. (2010). Belajar Dan Faktor-Faktor Yang Mempengaruhinya: Jakarta: Rineka Cipta

Sugiyono. (2009). Metode Penelitian Kualitatif dan R\&D. Bandung: Alfabeta.

Sulistawati. (2015, februari 12). guru pelajaran Matematika kelas XI IPS SMA N 6 Bandar 


\section{Lampung.}

Walgito, B. (2005). Bimbingan dan Penyuluhan di Sekolah . Yogyakarta: Yayasan Penerbit Fakultas Psikologi UGM. 
